\title{
In Memoriam : Clive Emsley (1944-2020), Jean-Claude Farcy (1945-2020), Dominique Kalifa (1957-2020)
}

Paul Lawrence

\section{(2) OpenEdition}

Electronic version

URL: https://journals.openedition.org/chs/2919

DOI: $10.4000 /$ chs.2919

ISSN: 1663-4837

Publisher

Librairie Droz

Printed version

Date of publication: 5 August 2021

Number of pages: 135

ISSN: 1422-0857

\section{Electronic reference}

Paul Lawrence, "In Memoriam : Clive Emsley (1944-2020), Jean-Claude Farcy (1945-2020), Dominique Kalifa (1957-2020)", Crime, Histoire \& Sociétés / Crime, History \& Societies [Online], vol. 25, n¹ | 2021, Online since 05 August 2021, connection on 10 November 2022. URL: http://journals.openedition.org/ chs/2919; DOI: https://doi.org/10.4000/chs.2919

This text was automatically generated on 10 November 2022.

All rights reserved 


\section{In Memoriam : Clive Emsley (1944-2020), Jean-Claude Farcy (1945-2020), Dominique Kalifa (1957-2020)}

\section{Paul Lawrence}

Crime, History \& Societies wishes to pay tribute to the lives and work of three important historians of crime and criminal justice, all of whom were closely associated with the work of the journal as members of its Editorial Board or Advisory Board. All three colleagues helped to shape the field of criminal justice history through their publications, teaching and academic leadership, and all three contributed significantly to the work of the journal since its founding in 1997.

\section{AUTHOR}

PAUL LAWRENCE

paul.lawrence[at]open.ac.uk 